\title{
The availability of items management responsibility as one of the requirements ISO 9001/2008 and Their Relationship to
} the Organization's Competitive.

\section{Sabrein Attia Mersal Gweuda}

Faculty of Physical Education for Girls, Alexandria University, Egypt.

\begin{abstract}
This research aims at identifying fact of applying management responsibility clauses as an ISO 9001/2008 requirement at faculty of physical education for girls, Alexandria University through identifying levels of clauses applications and analysis to determine agreement percentages of the more and the less advanced clauses in the field of application, through using case study as a type of descriptive method researches, and by applying to a random sample of (128) of teaching board staff of faculty as employees of administrative authority through a scientific codified questionnaire form, as results of analyzing mono contrast between the research sample opinion of management responsibility requirement clauses proved statistical significant differences of all requirement clauses except for clause of care of beneficiaries and planning whose significance was not proved. The results, as clarified by statistic analysis by using the average percentage, proved that the studied faculty could apply management responsibility as an important requirement of applying the approved international standard specification at the faculty.
\end{abstract}

Keywords: ISO 9001/2008 - Management Responsibility - Competitive Advantage.

\section{Introduction:}

$\mathrm{D}$ ue to globalization, there was an increased international concern about quality and its use by many organizations and considering a product/ service quality as an aimed important variable to offer services, beneficiaries, international standard specification was the most striking event as a quality control system, therefore, many organizations took procedures to apply obtainment requirements, also applying management responsibility requirement clause is the corner stone of applying all requirements clauses, accordingly qualifying to obtain its certificates as the starting point of sound application couples with supporting and assisting the supreme administration on a permanent basis for that International Organization for Standardization (ISO).

ISO 9001 is one of ISO 9000 standards specialized for use at any organization regardless of size including the offered service; also its requirements provide permanent development to the followed quality system (El-Dradka, 2008). For achieve uniting the system procedures and characteristics inconformity with quality adoption in all the organizations processes (Heizer and Ronder, 2001). Universities witness many challenges especially achieving quality standards and obtaining approval to be one of the best universities (El-Nagar, 2008).

So, it Necessary to making a complete change in administrative systems inside high education organization for advancing, their competitive capacities under local and international standards (Omar, 2005). Obtaining international standard specification as a modern quality system indicates to achieve a competitive advantage for universities outcomes in international markets (El-Azawi, 2002).

Faculty of Physical Education for girls, Alexandria University is an organization seeking obtaining international standard specification to improve its service quality and enhance its competitive position. Specification adopted by the faculty is ISO 9001/2008 fourth edition and was called identification due to main requirements required to be available in quality administration systems (ISO, 2008). It is the most integrated specification for covering all needs of any effective quality system (ElBakry, 2007). Management responsibility requirement is the most important among specification requirements due to the supreme management role in executing quality system through declaring and following quality policy, determining responsibilities and competences, availing sources, appointing the management representative and carrying out relevant regular reviewing (ISO, 2008).

Moreover, the researched faculty exerts exceptional efforts to apply the specification clauses specially under a system guaranteeing quality administration efficiency after approving by quality warranty and approval authority in (2013), also seeking ISO certificate is the key of its success and growth, success in designing and managing a quality system program is a strong base qualifying for agreeing with the global standard ISO specification targeted through applying ISO 9001/2008 as a step towards maintaining its competitive advantage.

This research aims : 
- Identifying levels of management responsibility and analysis to determine agreement percentages of the more and the less advanced clauses in the field of application the International Standard for the global standard ISO 9001/2008.

- The relationship between availability of international requirements for management responsibility and the competitive advantage of the college

\section{Procedures:}

Method: Case study as a descriptive method research.

Table (1):

The Main and the Explorative Research Community and Sample

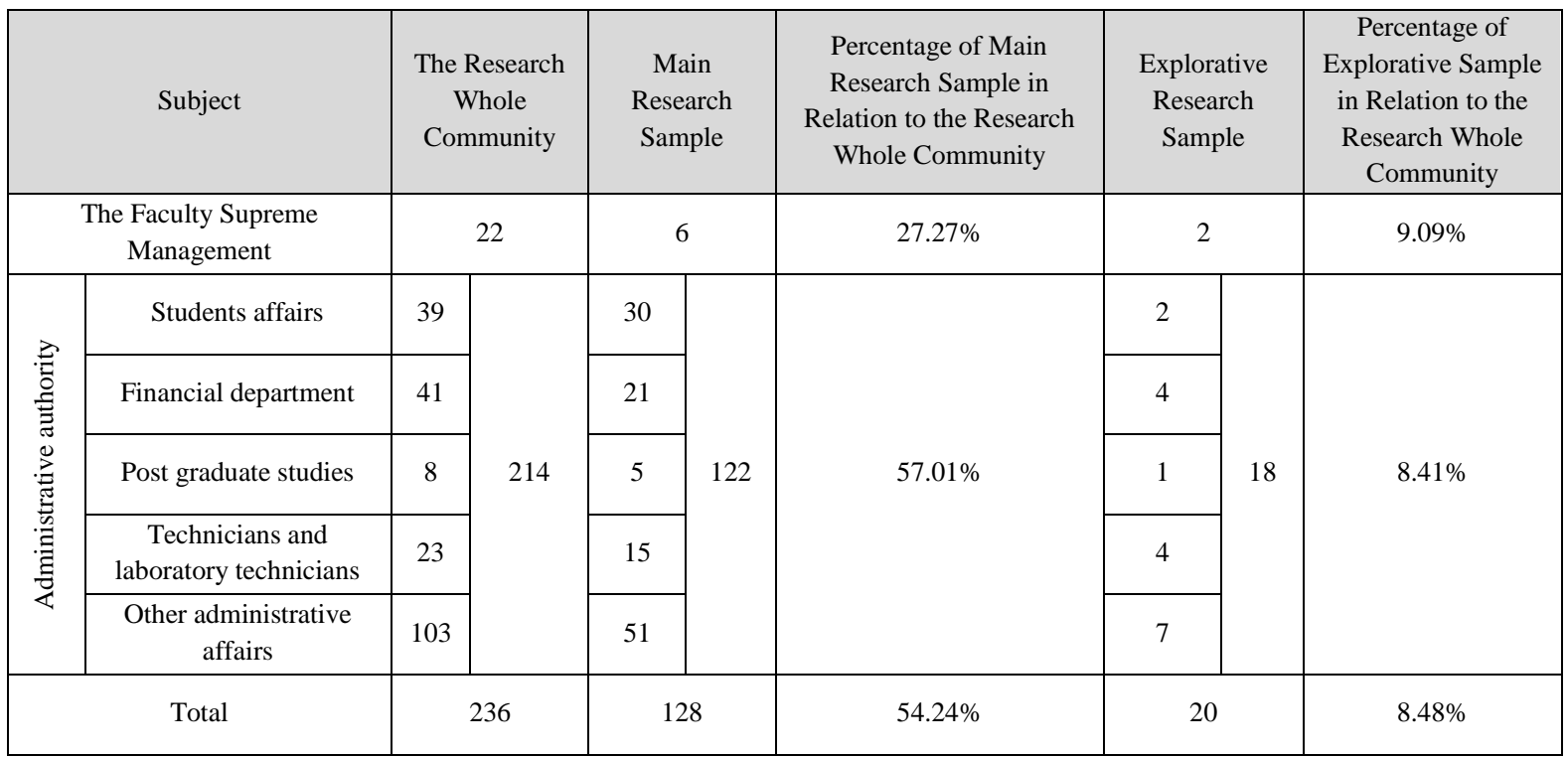

\section{Data Collection Tools}

A- Documents and Registrars Analysis: The researcher analyzed ISO 9000 versions of 200, 1994, 1987 and ISO 9001/2008, fourth edition

B- Questionnaire Form: A questionnaire form $\{$ Annex no. (1)\}. For the purpose of measuring the potential of the college in the design and management program quality system constitutes a base position to agree with the target specification through the application of for the global standard ISO 9001/2008 as a step towards the acquisition of competitive advantage.

\section{Scientific Coefficients of Questionnaire Forms}

\section{(A) Questionnaire Forms Validity}

1. Arbitrator's validity: The final questionnaire forms, was submitted to (6) teaching staff member $\{$ Annex no. (2)\}. The percentage of their agreement on the questionnaire form was between: $(83.33 \%$ to $100 \%)$ for everyone

\section{Research Community and Sample:}

A- Research Community: Faculty of physical education for girls, Alexandria University

B- Research Sample: Random samples of (128) of the whole research community reaching (236) represent $(54.24 \%)$.

Also, a sample of (20) subjects of the research whole community, outside the main sample represent $(8.48 \%)$ of the research whole community. 


\section{Results Discussion:}

To verify the research objective, the researcher carried out the following statistical coefficients:
A. Levene's Test for Equality of Variances: to determine values of $(F)$ calculated for clauses and significance level and indicator according to variable of administrative departments applying ISO 9001/2008 followed by the faculty.

Table (2):

Analyzing Equality of Variances between Research Sample Opinions of Management Responsibility Requirement in Questionnaire Form According to Administrative Applied for ISO 9001/2008 System Followed at the Faculty N=(128)

\begin{tabular}{|c|c|c|c|c|c|c|}
\hline S.N & Clauses & Contrast Source & $\begin{array}{c}\text { Total } \\
\text { Squares }\end{array}$ & $\begin{array}{c}\text { Freedom } \\
\text { Degree }\end{array}$ & $\begin{array}{c}\text { Average } \\
\text { Square }\end{array}$ & $\begin{array}{c}\text { "F" } \\
\text { Value }\end{array}$ \\
\hline 1 & $\begin{array}{c}\text { Supreme Management } \\
\text { Obligation (Faculty } \\
\text { Council) }\end{array}$ & $\begin{array}{c}\text { Between groups } \\
\text { Inside groups } \\
\text { Total }\end{array}$ & $\begin{array}{c}3.918 \\
10.074 \\
13.992\end{array}$ & $\begin{array}{c}5 \\
122 \\
127\end{array}$ & $\begin{array}{l}0.784 \\
0.083\end{array}$ & $* 9.5$ \\
\hline 2 & Carrying of Beneficiaries & $\begin{array}{c}\text { Between groups } \\
\text { Inside groups } \\
\text { Total }\end{array}$ & $\begin{array}{c}3.666 \\
30.264 \\
33.93\end{array}$ & $\begin{array}{c}5 \\
122 \\
127\end{array}$ & $\begin{array}{l}0.733 \\
0.248\end{array}$ & 3 \\
\hline 3 & Quality Policy & $\begin{array}{c}\text { Between groups } \\
\text { Inside groups } \\
\text { Total }\end{array}$ & $\begin{array}{c}22.236 \\
32.218 \\
54.55\end{array}$ & $\begin{array}{c}5 \\
122 \\
127\end{array}$ & $\begin{array}{l}4.467 \\
0.264\end{array}$ & $* 17$ \\
\hline 4 & Planning & $\begin{array}{c}\text { Between groups } \\
\text { Inside groups } \\
\text { Total }\end{array}$ & $\begin{array}{c}5.879 \\
49.239 \\
55.17\end{array}$ & $\begin{array}{c}5 \\
122 \\
127\end{array}$ & $\begin{array}{l}1.176 \\
0.404\end{array}$ & 2.9 \\
\hline 5 & $\begin{array}{l}\text { Responsibilities, } \\
\text { Competences and } \\
\text { Communications }\end{array}$ & $\begin{array}{c}\text { Between groups } \\
\text { Inside groups } \\
\text { Total }\end{array}$ & $\begin{array}{l}16.815 \\
21.053 \\
37.867\end{array}$ & $\begin{array}{c}5 \\
122 \\
127\end{array}$ & $\begin{array}{l}3.363 \\
0.173\end{array}$ & $* 19$ \\
\hline 6 & Management Review & $\begin{array}{c}\text { Between groups } \\
\text { Inside groups } \\
\text { Total }\end{array}$ & $\begin{array}{c}2.09 \\
7.932 \\
10.022\end{array}$ & $\begin{array}{c}5 \\
122 \\
127\end{array}$ & $\begin{array}{l}0.418 \\
0.065\end{array}$ & $* 6.4$ \\
\hline & Total Degree & $\begin{array}{c}\text { Between groups } \\
\text { Inside groups } \\
\text { Total }\end{array}$ & $\begin{array}{c}1.039 \\
1.92 \\
2.959\end{array}$ & $\begin{array}{c}5 \\
122 \\
127\end{array}$ & $\begin{array}{l}0.208 \\
0.016\end{array}$ & $* 13$ \\
\hline
\end{tabular}

* "F" tabular value at (122.5) and significant level $(0.01)=(3.174)$

From Table no. (2) according to statistical analysis results, there is a considerable agreement between their opinions through what was clarified by " $F$ " values indicating that it is higher than its tabular value at significant level (0.01) at value (3.174) which proved a statistical significant difference of all items of management responsibility requirement except what was related to clauses of caring of beneficiaries and planning whose significance was not proved which can be attributed by the researcher to administrative tasks determined for every department according to specialty and offered service, for that, the researcher decided to verifying significance and direction of difference proved by mono contrast analysis through using Scheffe Test.

B. Scheffe Test: To know significance and direction of difference between opinions of the research sample of management responsibility requirement, where showed significant differences between them with removing clauses of care of beneficiaries and planning between which the research sample opinions couldn't prove considerable contrast. 
Table (6):

Scheffe Test Differences Direction between Arithmetic Means According to Administrative Departments Variable Applying ISO 9001/2008 Followed in the Faculty $\mathrm{N}=(128)$

\begin{tabular}{|c|c|c|c|c|c|c|c|c|c|c|}
\hline 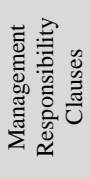 & $\begin{array}{l}\frac{0}{\tilde{\Xi}} \\
\text { ڤ్స }\end{array}$ & 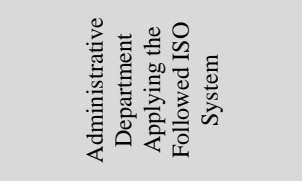 & 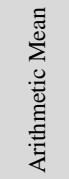 & 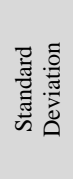 & 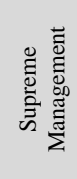 & 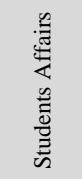 & 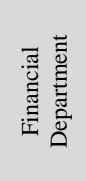 & 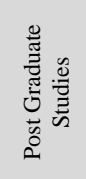 & 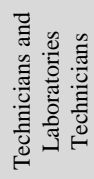 & 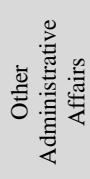 \\
\hline \multirow{6}{*}{ 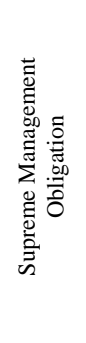 } & 6 & Supreme Management & 2.833 & 0.303 & - & & & & & \\
\hline & 30 & Students Affairs & 2.408 & 0.222 & 0.425 & - & & & & \\
\hline & 21 & Financial Department & 2.143 & 0.331 & 0.690 & 0.265 & - & & & \\
\hline & 5 & Post graduate Studies & 2.700 & 0.112 & 0.133 & 0.292 & $0.557^{*}$ & - & & \\
\hline & 15 & $\begin{array}{c}\text { Technicians and Laboratories } \\
\text { Technicians }\end{array}$ & 2.100 & 0.338 & 0.733 & 0.308 & 0.043 & $0.600^{*}$ & - & \\
\hline & 51 & Other Administrative Affairs & 2.333 & 0.294 & 0.500 & 0.075 & 0.190 & 0.367 & $0.233^{*}$ & - \\
\hline \multirow{6}{*}{ 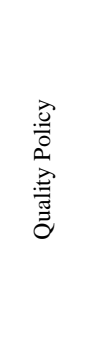 } & 6 & Supreme Management & 2.667 & 0.516 & - & & & & & \\
\hline & 30 & Students Affairs & 2.467 & 0.507 & 0.200 & - & & & & \\
\hline & 21 & Financial Department & 1.476 & 0.512 & $1.191^{*}$ & $0.991^{*}$ & - & & & \\
\hline & 5 & Post graduate Studies & 2.200 & 0.447 & 0.367 & 0.267 & 0.724 & - & & \\
\hline & 15 & $\begin{array}{c}\text { Technicians and Laboratories } \\
\text { Technicians }\end{array}$ & 2.133 & 0.640 & 0.533 & 0.333 & $0.657^{*}$ & 0.067 & - & \\
\hline & 51 & Other Administrative Affairs & 2.647 & 0.483 & 0.020 & 0.180 & $1.171^{*}$ & 0.447 & $0.514^{*}$ & - \\
\hline \multirow{5}{*}{ 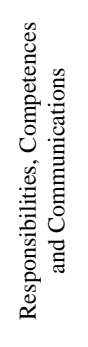 } & 6 & Supreme Management & 2.833 & 0.408 & - & & & & & \\
\hline & 21 & Financial Department & 2.762 & 0.436 & 0.071 & 0.129 & - & & & \\
\hline & 5 & Post graduate Studies & 3.000 & 0.000 & 0.167 & 0.367 & 0.238 & - & & \\
\hline & 15 & $\begin{array}{l}\text { Technicians and Laboratories } \\
\text { Technicians }\end{array}$ & 1.733 & 0.594 & $1.100^{*}$ & $0.900^{*}$ & $1.029^{*}$ & $1.267 *$ & - & \\
\hline & 51 & Other Administrative Affairs & 2.902 & 0.300 & 0.069 & 0.269 & 0.140 & 0.098 & $1.169^{*}$ & - \\
\hline \multirow{6}{*}{ 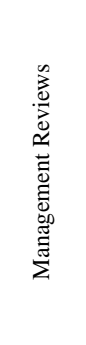 } & 6 & Supreme Management & 2.625 & 0.468 & - & & & & & \\
\hline & 30 & Students Affairs & 2.525 & 0.273 & 0.100 & - & & & & \\
\hline & 21 & Financial Department & 2.321 & 0.308 & 0.304 & 0.204 & - & & & \\
\hline & 5 & Post graduate Studies & 2.850 & 0.137 & 0.225 & 0.325 & $0.529 *$ & - & & \\
\hline & 15 & $\begin{array}{l}\text { Technicians and Laboratories } \\
\text { Technicians }\end{array}$ & 2.707 & 0.260 & 0.082 & 0.182 & 0.385 & 0.143 & - & \\
\hline & 51 & Other Administrative Affairs & 2.466 & 0.187 & 0.159 & 0.059 & 0.144 & 0.384 & 0.241 & - \\
\hline \multirow{6}{*}{ 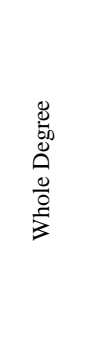 } & 6 & Supreme Management & 2.743 & 0.308 & - & & & & & \\
\hline & 30 & Students Affairs & 2.531 & 0.122 & 0.212 & - & & & & \\
\hline & 21 & Financial Department & 2.412 & 0.126 & 0.331 & 0.119 & - & & & \\
\hline & 5 & Post graduate Studies & 2.777 & 0.089 & 0.034 & 0.246 & 0.315 & - & & \\
\hline & 15 & $\begin{array}{l}\text { Technicians and Laboratories } \\
\text { Technicians }\end{array}$ & 2.442 & 0.106 & 0.301 & 0.090 & 0.030 & 0.305 & - & \\
\hline & 51 & Other Administrative Affairs & 2.563 & 0.101 & 0.180 & 0.032 & 0.151 & 0.214 & 0.121 & - \\
\hline
\end{tabular}

* Significant level $(0.01)=(0.463)$ 
From Table (3) despite difference proved by mono contrast analysis, where Scheffe Test carried out to know significance and direction of differences couldn't prove clear significance for such differences specially the test whole degree. The researcher used norm of dividing the average percentage value on the research sample opinions after dealing with opinions to represent one direction.

\section{The Percentage of Medium}

Which is calculating percentage arithmetic mean depending on medium value division standard (Carifio and Perla, 2007).

Table (4):

Arithmetic Mean Percentage, Degree, Status and Grade

\begin{tabular}{|c|c|c|c|}
\hline Arithmetic Mean Percentage & Degree & Status & Grade \\
\hline From $33.33 \%$ - to $52.33 \%$ & From 1 to 1.66 & Unapplied and undocumented & Weak \\
\hline From $52.34 \%$ - to $77.67 \%$ & From 1.67 to 2.33 & Applied and undocumented & Average \\
\hline From $77.68-$ to $100 \%$ & From 2.34 to 3 & Applied and documented & Strong \\
\hline
\end{tabular}

\section{For obligation of supreme management and its items}

Table (5):

Arithmetic Mean, Standard Deviation, Percentage, Status and Grade of Clauses of Supreme Administration Obligation and its Competences $(\mathrm{N}=128)$

\begin{tabular}{|c|c|c|c|c|c|c|}
\hline S & Clauses and Its Items & $\begin{array}{c}\text { Arithmetic } \\
\text { Mean }\end{array}$ & $\begin{array}{l}\text { Standard } \\
\text { Deviation }\end{array}$ & Percentage & Status & Grade \\
\hline 1 & Supreme Management Obligation & 2.33 & 0.33 & $77.66 \%$ & $\begin{array}{c}\text { Applied and } \\
\text { undocumented }\end{array}$ & Average \\
\hline & $\begin{array}{c}\text { 1-1 There is a documented commitment by the supreme } \\
\text { management to approve the permanent } \\
\text { improvement of quality system as a fixed work } \\
\text { method at the faculty. }\end{array}$ & 2.73 & 0.45 & $90.89 \%$ & $\begin{array}{l}\text { Applied and } \\
\text { documented }\end{array}$ & Strong \\
\hline & $\begin{array}{c}\text { 1-2 There is a documented commitment by the supreme } \\
\text { management to avail necessary resources to achieve } \\
\text { quality in conformity with beneficiates needs. }\end{array}$ & 2.33 & 0.69 & $77.60 \%$ & $\begin{array}{l}\text { Applied and } \\
\text { Undocumented }\end{array}$ & Average \\
\hline & $\begin{array}{l}\text { 1-3 The supreme management shall follow up the } \\
\text { management regularly to verify efficiency of the } \\
\text { follow quality administration system in conformity } \\
\text { with permanent development. }\end{array}$ & 1.96 & 0.70 & $65.36 \%$ & $\begin{array}{c}\text { Applied and } \\
\text { undocumented }\end{array}$ & Average \\
\hline
\end{tabular}

From Table (5) It is clear that this clauses is neither applied nor documented with a percentage of average opinions of the research sample reached $(77.66 \%)$, although there is a commitment documented by the supreme management to approve the permanent approval of quality system as a fixed work method at the faculty and applied with a percentage of average opinions of the research sample reached $(90.89 \%)$, which means that it is far from contact and, accordingly, less advanced in the field of specification application.
To making establishments follow a quality administration system due to its effective role in improving their administrative operation and strategic planning which will enable them to maintain existence and there form finding a competitive advantages among counterparts (Prajogo and Brown, 2004).

Also; that availing requirements of applying quality administration system, especially in nonprofit organization is an important affair to improve their performance, increase their productivity and alleviating suffering from lack of finance (Paul, 2004). 


\section{For clauses of caring of beneficiaries and its items}

Table (5):

Arithmetic Mean, Standard Deviation, Percentage, Status and Grade of

Clauses of Caring of Beneficiaries and Its Items $\mathrm{N}=(128)$

\begin{tabular}{|c|c|c|c|c|c|c|c|}
\hline S & & Clauses and Its Items & $\begin{array}{l}\text { Arithmetic } \\
\text { Mean }\end{array}$ & $\begin{array}{l}\text { Standard } \\
\text { Deviation }\end{array}$ & Percentage & Status & Grade \\
\hline \multirow[t]{7}{*}{2} & & Caring of Beneficiaries & 2.41 & 0.26 & $80.47 \%$ & $\begin{array}{l}\text { Applied and } \\
\text { documented }\end{array}$ & Strong \\
\hline & & $\begin{array}{l}\text { The Supreme management of the faculty depends on a } \\
\text { mechanism through which beneficiary's needs are to be } \\
\text { known. }\end{array}$ & 2.64 & 0.54 & $88.02 \%$ & $\begin{array}{l}\text { Applied and } \\
\text { documented }\end{array}$ & Strong \\
\hline & $2-2$ & $\begin{array}{l}\text { The Supreme management avails all potentials according } \\
\text { to beneficiaries needs after perfect determination at the } \\
\text { relevant departments and documentation in a register } \\
\text { approved for this purpose. }\end{array}$ & 2.67 & 0.47 & $89.06 \%$ & $\begin{array}{l}\text { Applied and } \\
\text { documented }\end{array}$ & Strong \\
\hline & $2-3$ & $\begin{array}{l}\text { There is a mechanism approved for reviewing } \\
\text { beneficiaries needs }\end{array}$ & 2.17 & 0.70 & $72.40 \%$ & $\begin{array}{l}\text { Applied and } \\
\text { undocumented }\end{array}$ & Average \\
\hline & $2-4$ & $\begin{array}{l}\text { There is a mechanism through which we can know how } \\
\text { far the supreme management can meet beneficiaries need } \\
\text { permanently. }\end{array}$ & 2.53 & 0.55 & $84.38 \%$ & $\begin{array}{l}\text { Applied and } \\
\text { documented }\end{array}$ & Strong \\
\hline & $2-5$ & $\begin{array}{l}\text { All required needs are to be applied to the followed } \\
\text { quality system pursuant to meeting beneficiaries needs } \\
\text { pursuant to a system approved for this purpose. }\end{array}$ & 1.95 & 0.67 & $64.84 \%$ & $\begin{array}{l}\text { Applied and } \\
\text { undocumented }\end{array}$ & Average \\
\hline & $2-6$ & $\begin{array}{l}\text { There is an approved mechanism through which the } \\
\text { management can identify amends affecting needs of } \\
\text { beneficiaries of employees concerned about execution } \\
\text { each at his/her work place. }\end{array}$ & 2.52 & 0.52 & $84.11 \%$ & $\begin{array}{l}\text { Applied and } \\
\text { documented }\end{array}$ & Strong \\
\hline
\end{tabular}

It is clear from results of Table no. (6) that this clause is, applied and documented at percentage of average research sample opinions reached $(80.47 \%)$, despite results of weakness of documenting an approved mechanisms documented by the supreme management for reviewing beneficiaries needs and applying amends to the followed quality system depending on meeting such needs pursuant to system approved for this purpose as they are two elements their procedures are actually applied at percentage of average sample opinions reached $(72.40 \%$, $64.81 \%$ ) respectively, yet, the Table results has, at percentage of average research sample opinions between
$(89.06 \%, 84.11 \%)$. Such results make this clause closer to agreement for application and represent a strong point for management in the field of applying the followed specification.

That quality administration is an administrative method whose philosophy supports achieving requirement, needs and expectations of beneficiaries through meeting its requirements, needs and trying to know how far it is satisfied with the offered service (Donovan and Budgol, 2005). Also, that service improvement is the most important element of their organizations (Berry and Parasuraman, 1992).

\section{As for quality policy clauses and its items}

Table (7):

Arithmetic Mean, Standard Deviation, Percentage, Status and Grade of Quality Policy and Its Items

$\mathrm{N}=(128)$

\begin{tabular}{|c|c|c|c|c|c|c|}
\hline S & Clauses and Its Items & $\begin{array}{l}\text { Arithmetic } \\
\text { Mean }\end{array}$ & $\begin{array}{l}\text { Standard } \\
\text { Deviation }\end{array}$ & Percentage & Status & Grade \\
\hline \multirow[t]{4}{*}{3} & Quality Policy & 2.65 & 0.22 & $88.45 \%$ & $\begin{array}{l}\text { Applied } \\
\text { and } \\
\text { documented }\end{array}$ & Strong \\
\hline & $\begin{array}{c}\text { 3-1 There is a quality policy suitable for the faculty } \\
\text { objectives interns of resources needed for } \\
\text { achievement. }\end{array}$ & 2.73 & 0.44 & $91.15 \%$ & $\begin{array}{c}\text { Applied } \\
\text { and } \\
\text { documented } \\
\end{array}$ & Strong \\
\hline & $\begin{array}{l}\text { 3-2 Quality policy affirms the supreme management } \\
\text { obligation to achieve and develop quality. }\end{array}$ & 2.59 & 0.49 & $86.46 \%$ & $\begin{array}{l}\text { Applied } \\
\text { and } \\
\text { documented }\end{array}$ & Strong \\
\hline & $\begin{array}{cc}\text { T-3 } & \text { There is a quality policy preparing a clear frame } \\
\text { work to determine mine quality objectives. }\end{array}$ & 2.59 & 0.49 & $86.20 \%$ & $\begin{array}{l}\text { Applied } \\
\text { and }\end{array}$ & Strong \\
\hline
\end{tabular}




\begin{tabular}{|c|c|c|c|c|c|c|}
\hline S & Clauses and Its Items & $\begin{array}{l}\text { Arithmetic } \\
\text { Mean }\end{array}$ & $\begin{array}{l}\text { Standard } \\
\text { Deviation }\end{array}$ & Percentage & Status & Grade \\
\hline & & & & & documented & \\
\hline & $\begin{array}{l}\text { 3-4 Quality policy is easily drafted and understood by } \\
\text { all the faculty administration levels. }\end{array}$ & 2.82 & 0.39 & $94.01 \%$ & $\begin{array}{l}\text { Applied } \\
\text { and } \\
\text { documented }\end{array}$ & Strong \\
\hline & $\begin{array}{l}\text { 3-5 All the faculty employees shall be informed of } \\
\text { quality policy and affirming understanding and } \\
\text { executives }\end{array}$ & 2.85 & 0.36 & $95.05 \%$ & $\begin{array}{l}\text { Applied } \\
\text { and } \\
\text { documented }\end{array}$ & Strong \\
\hline & $\begin{array}{l}\text { 3-6 The supreme management shall make regular } \\
\text { reviews to verify quality policy suitability and } \\
\text { development. }\end{array}$ & 2.34 & 0.66 & $77.86 \%$ & $\begin{array}{l}\text { Applied } \\
\text { and } \\
\text { documented }\end{array}$ & Strong \\
\hline
\end{tabular}

Table no. (7) proves that percentage of average research sample opinion that ranged between $(77.86 \%, 95.05 \%)$ ,showed that percentage of average sample opinions for this clause reached $(88.54 \%)$ which indicate that quality policy as a clause of management responsibility requirement is applied and documented and represent a strong agreement point in applying the followed specification by the faculty. Information and communication systems produced by the concerned organizations through which employees are informed of objectives required to be achieved and verifying understanding the same and existence of indicators for measuring their results is very important for quality management system needed to be achieved (Hassan, 2003).

\section{For Planning Clause and Its Items}

Table (8)

Arithmetic Mean, Standard Deviation, Percentage, Status and Grade of Planning Clause and Its Items $\quad \mathrm{N}=(128)$

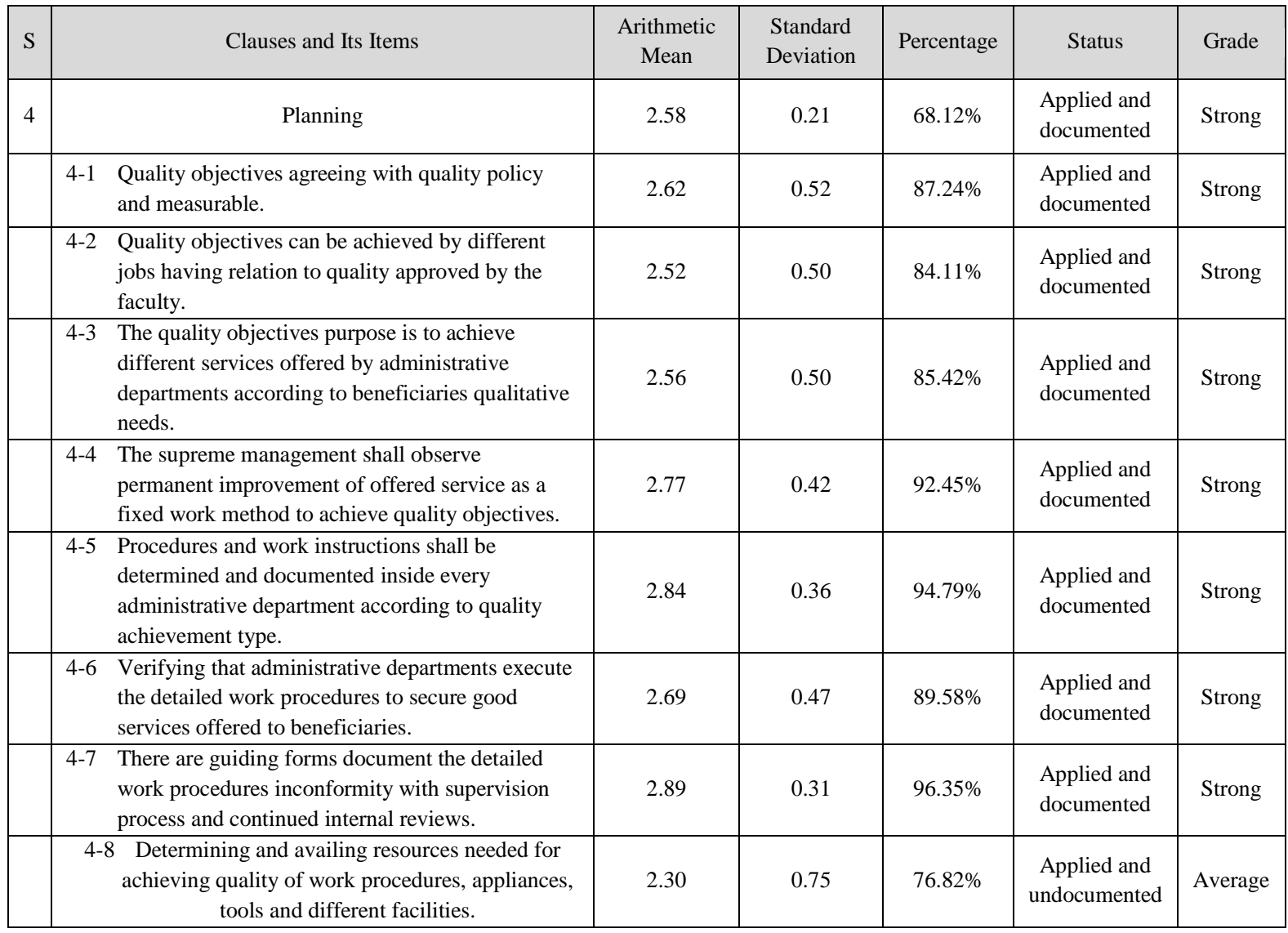




\begin{tabular}{|c|c|c|c|c|c|c|}
\hline S & Clauses and Its Items & $\begin{array}{l}\text { Arithmetic } \\
\text { Mean }\end{array}$ & $\begin{array}{l}\text { Standard } \\
\text { Deviation }\end{array}$ & Percentage & Status & Grade \\
\hline & $\begin{array}{c}\text { 4-9 There is a certain mechanism through which we } \\
\text { can know the beneficiaries feedback inside every } \\
\text { administrative department }\end{array}$ & 2.33 & 0.62 & $77.60 \%$ & $\begin{array}{c}\text { Applied and } \\
\text { undocumented }\end{array}$ & Average \\
\hline & $\begin{array}{l}\text { 4-10 Beneficiary's opinion should be taken when } \\
\text { designing plans of the followed quality system } \\
\text { improvement and development. }\end{array}$ & 2.30 & 0.66 & $76.82 \%$ & $\begin{array}{c}\text { Applied and } \\
\text { undocumented }\end{array}$ & Average \\
\hline
\end{tabular}

Table (8) proves that percentage of average sample opinions of this clause which reached $(86.12 \%)$. Planning clause as requirement is applied and documented and represents a strong agreement point in applying the followed specification by the faculty. That the supreme management direction to strategic planning and permanent improvement may improve their abilities to use resources at has to achieve its purposes and develop its performance and skills in inconformity with the university competitive advantage (Madhom and Eltala, 2006).

\section{For Clause of Responsibilities, Competences, Communications and Its Items}

Table (9)

Arithmetic Mean, Standard Deviation, Percentage, Status and Grade of Responsibilities, Competence, Communications and Its Items $\mathrm{N}=(128)$

\begin{tabular}{|c|c|c|c|c|c|c|}
\hline S & Clauses and Its Items & $\begin{array}{l}\text { Arithmetic } \\
\text { Mean }\end{array}$ & $\begin{array}{c}\text { Standard } \\
\text { Deviation }\end{array}$ & Percentage & Status & Grade \\
\hline 5 & Responsibilities, Competence and Communications & 2.58 & 0.21 & $68.12 \%$ & $\begin{array}{l}\text { Applied and } \\
\text { Documented }\end{array}$ & Strong \\
\hline & $\begin{array}{ll}\text { 5-1 } & \text { Determining and documenting responsibilities and } \\
\text { competences related to relationship to quality at all } \\
\text { administrative departments. }\end{array}$ & 2.68 & 0.48 & $89.32 \%$ & $\begin{array}{l}\text { Applied and } \\
\text { documented }\end{array}$ & Strong \\
\hline & $\begin{array}{l}\text { 5-2 The faculty has an internal communication system } \\
\text { including holding regular meetings with employees of } \\
\text { different administrative departments and the concerned to } \\
\text { discuss the efficiency of quality administration system. }\end{array}$ & 2.63 & 0.52 & $87.76 \%$ & $\begin{array}{l}\text { Applied and } \\
\text { documented }\end{array}$ & Strong \\
\hline & $\begin{array}{l}\text { 5-3 ISO supreme management representatives shall supervise } \\
\text { applying quality international specification clauses. }\end{array}$ & 2.43 & 0.59 & $77.86 \%$ & $\begin{array}{l}\text { Applied and } \\
\text { documented }\end{array}$ & Strong \\
\hline & $\begin{array}{l}\text { 5-4 ISO supreme management representative shall report } \\
\text { regulars efficiency of quality administration system } \\
\text { performance enhanced by the followed system permanent } \\
\text { development requirements. }\end{array}$ & 2.74 & 0.47 & $91.41 \%$ & $\begin{array}{l}\text { Applied and } \\
\text { documented }\end{array}$ & Strong \\
\hline & $\begin{array}{l}\text { 5-5 ISO supreme administration shall promote awareness of } \\
\text { importance of achieving beneficiaries needs of the } \\
\text { faculty services under the followed quality system. }\end{array}$ & 2.68 & 0.55 & $89.32 \%$ & $\begin{array}{l}\text { Applied and } \\
\text { documented }\end{array}$ & Strong \\
\hline
\end{tabular}

Table (9) proves that this clause elements are applied and documented at percentages from $(77.86 \%, 91.41 \%)$, accordingly the percentage of average research sample opinion which reached $(87.11 \%)$, this clause as a clause of management responsibility requirement is applied and documented and represents a strong agreement point in applying the followed specification by the faculty. That obtaining ISO 9001 by the organization may depend on indicators of its administrative information system efficiency and, in turn, the ability to document it information and tracks through a good communication network (Hassan, 2003). Thus, all employees participation in achieving the required quality through allowing them to participate in discussions and field application of their ideas and opinions through availing internal communication systems granting them an amount contributing in offering excellent service (El-Wadi and Zogbi, 2001). 


\section{For Management Reviews Clause and Its Items}

Table (10)

Arithmetic Mean, Standard Deviation, Percentage, Status and Grade of Management Reviews and Its Items N = (128)

\begin{tabular}{|c|c|c|c|c|c|c|}
\hline S & Clauses and Its Items & $\begin{array}{c}\text { Arithmetic } \\
\text { Mean }\end{array}$ & $\begin{array}{c}\text { Standard } \\
\text { Deviation }\end{array}$ & Percentage & Status & Grade \\
\hline 6 & Management Reviews & 2.53 & 0.15 & 84.45 & $\begin{array}{l}\text { Applied and } \\
\text { documented }\end{array}$ & Strong \\
\hline & $\begin{array}{ll}\text { 6-1 Supreme management assure that management } \\
\text { representatives carry out internal review of quality } \\
\text { management system regularly. }\end{array}$ & 2.72 & 0.50 & 90.63 & $\begin{array}{l}\text { Applied and } \\
\text { documented }\end{array}$ & Strong \\
\hline & $\begin{array}{ll}\text { 6-2 } & \text { Administrative reviews shall result in determining } \\
\text { opportunities of improving quality system efficiency } \\
\text { including quality policy and objectives. }\end{array}$ & 2.38 & 0.64 & 79.43 & $\begin{array}{l}\text { Applied and } \\
\text { documented }\end{array}$ & Strong \\
\hline & $\begin{array}{l}\text { 6-3 Clauses of supreme management reviews shall include } \\
\text { results of internal reviews of quality, information } \\
\text { about beneficiates complaints and how far services } \\
\text { conform to the followed quality system objectives. }\end{array}$ & 2.55 & 0.57 & 85.16 & $\begin{array}{l}\text { Applied and } \\
\text { documented }\end{array}$ & Strong \\
\hline & $\begin{array}{l}\text { 6-4 Supreme management reviews include taking } \\
\text { procedures to develop the offered services quality } \\
\text { inconformity with beneficiates requirements and } \\
\text { availing needed resources. }\end{array}$ & 2.51 & 0.28 & 83.55 & $\begin{array}{l}\text { Applied and } \\
\text { documented }\end{array}$ & Strong \\
\hline
\end{tabular}

Table (10) status that clauses of management reviews and its items are applied and documented at percentage of average research sample responses research $(84.45 \%)$, also all this clauses items are applied and documented at percentage between $(79.43 \%, 90.63 \%)$. Service quality evaluations depend on indicators related to their characteristics through beneficiates expectation and personal need which can be reached through applying work procedures and creating administrative systems with training human resources and searching for distinction in relationship to beneficiates (Nour El-Din, 2007).

D. Spearman correlation coefficient: Spearman coefficient was used correlation to find the relationship between the availability of the requirements of the terms of management responsibility and competitive advantage for College.

Table (15):

Arithmetic Mean, Standard Deviation and Coefficient of Spearman correlation to the level of denotation $\mathrm{N}=(128)$

\begin{tabular}{|c|c|c|c|c|}
\hline Clauses & $\begin{array}{c}\text { Arithmetic } \\
\text { Mean }\end{array}$ & $\begin{array}{c}\text { Standard } \\
\text { Deviation }\end{array}$ & $\begin{array}{c}\text { Spearman correlation } \\
\text { coefficient }\end{array}$ & $\begin{array}{c}\text { The level of } \\
\text { significance }\end{array}$ \\
\hline $\begin{array}{c}\text { Supreme Management Obligation } \\
\text { (Faculty Council) }\end{array}$ & 2.33 & 0.33 & 0.654 & 0.00 \\
\hline Carrying of Beneficiaries & 2.41 & 0.26 & 0.733 & 0.00 \\
\hline Quality Policy & 2.65 & 0.22 & 0.714 & 0.00 \\
\hline Planning & 2.58 & 0.21 & 0.391 & 0.645 \\
\hline $\begin{array}{c}\text { Responsibilities, Competences and } \\
\text { Communications }\end{array}$ & 2.61 & 0.31 & 0.729 & 0.00 \\
\hline Management Review & 2.53 & 0.15 & & 0.00 \\
\hline
\end{tabular}

* Significant level (0.01)

Table (15) its significant Correlation coefficients at the level of moral (0.01). Where it is clear that the availability of management responsibility items, which ranged between $(0.391,0.733)$, and the significance level $(0.00)$ which is less than (0.05), which indicates that there is sufficient evidence through research sample views that there is a relationship between those items as one of the requirements of the standard international Standard for the 
global standard ISO 9001 / 2008 in the Faculty of Physical Education for Girls in Alexandria University under study and gain their competitive advantage.

Universities may have competitive advantages through discovering new and preferred method for competitions service sector they belong to, and transfer this to different labor markets, accordingly they can respond to different environmental, social and economic changes in activating their competitive abilities (Bannker, 2005).

\section{Conclusions:}

- Results of mono agreement analysis between the research sample opinions of management responsibility requirement proved statistical significant differences for all requirement clauses with the exception of concerning about beneficiaries and planning items whose significance were not proved.

- Also Scheffe Test carries out to know significance and direction of differences for clauses of management responsibility proved difficulty of proving a clear significance of such differences especially in relation to the test whole degree.

- Statistical analysis by using percentage of average proved that the studied faculty would apply management responsibility requirement as the most important requirement of applying the international standard specification approved at the faculty at percentage from $(77.66 \%, 88.45 \%)$

- The most applied and documented distinctive clauses of clauses of management responsibility requirement of specification are (quality policy $(88.45 \%)$ responsibilities, competences and communications $(87.14 \%)$ - planning $(86.12 \%)$ - management reviews $(84.48 \%)$ - caring of beneficiaries $(80.47 \%)$ ) and they are closer to agreement with approved interactional standard speciation and represent a strong point of the faculty quality administration system.

- Supreme management obligation clause (77.66\%) I the least applied management responsibility requirements clause as it's undocumented despite application, the clause far from agreement with specification clauses and represents a weak point for the faculty quality administration system.

- There is a relationship between the terms of a management responsibility as one of the requirements of the international standard requirements for the global standard ISO 9001/2008 in the Faculty of
Physical Education for Girls in Alexandria University and gain their competitive advantage.

\section{Recommendations:}

- Obtaining a certificate of identification with a agreementing specification of international organization for specifications and standards is not an objective, rather, the objective is improving the faculties performance towards adopting systems of quality administration which may improve the applied services and, accordingly, distinction.

- For success of applying for the global standard ISO $9001 / 2008$ and making the faculty excels to achieve competitive advantages in an effective way the following shall be done.

- $\quad$ Availing and maintaining infrastructure needed for success of this followed quality system.

- Selecting university and administrative leaderships contributing in the success of any change helping in availing organizational and academic climate encouraging on creation under quality management.

- Availing computers networks, to store all statistical information and data of different administrative operation, at the faculty through administrative and communicative system developing work and the offered services quality and consolidating the some in conformity with the competitive updates.

- Having promotional programs to identify the faculty and services it offers and changes taken place as an approved faculty through carrying out civil researches depending on modern scientific examples to know aspects of achieving the offered services in conformity with development and making it a more competitive advantage that its counter parts.

\section{References:}

1. Bannker, M., 2005, "Total Quality Management in High Education", 2nd ed., Putnam Publishing Group, New York, Pp 41.

2. Berry, A. and Parasuraman, G. 1992, "Prescriptions for a Service Quality Revolution in America ", Organizational Dynamics, spring, Pp 14.

3. Carifio, J.and Perla, J., 2007, "Ten common misunderstandings, misconceptions", persistent myths and urban legends about Likert scales and Likert Response Aormats and their Antidotes ", 
Research published in Journal of Social Sciences, Vol. 3, Iss 3, Pp 116.

4. Donovan, M.R. and Budgol, M.,2005," The implementation of the TQM in Poland", Research published in Journal of The TQM Magazine, Vol 17, No 2, Pp 3.

5. El-Azawi, M.A., 2002, "Requirements of University Quality Administration According to ISO 9001/2000 a research published in the Future Researches Magazine", Future Studies Centre, El Hadba Faculty, El Mosel University, Iraq, Iss 3, Pp 56.

6. El-Bakry, S.M., 2007, "Complete Quality Administration", El Dar El Gameia, Alexandria, Egypt, Pp 334.

7. El-Dradka, M.S., 2008, "Integrated Quality Administration and Beneficiaries Services", First edition, Dar Safa for publishing and distribution, Oman, Pp 26.

8. El-Nagar, F., 2008, "Universities Administration by Integrated Quality", Ithrak for distribution and publishing, Second edition, Pp 19.

9. El-Wadi, M.H and Zogbi, A.F., 2001, "Needs of Integrated Quality Administration as a Tool for Achieving the Competitive Advantage at Jordanian Universities (Analytical Study)", a research published in the Arab Magazine to guarantee university education quality, Eighth issue, Fourth volume, Jordan, Pp 90.

10.Hassan, M.M., 2003, "Effect of Indicators of Administrative Information Systems in Establishing Requirements of ISO 9001/2000 (an Explorative Study in a Sample of Organizations under Qualification to Obtain ISO 9001/2000)", a research published at Magazine of Faculty of Administration and Economy, El Mosel University Iraq, Pp 56.
11.Heizer, J.and Ronder, B., 2001, " Operation management", 6th ed, prentice Hall, Inc, New Jersey, USA, Pp 18

12.ISO 9001/2008, 2008, Fourth edition, Arab version, copy rights office of ISO, Geneva, Switzerland, Pp $\mathrm{V}, 4-6$.

13.Madhom, M. and Eltala, S., 2006, "How far Items of National Authority Form for Approval and Quality are Available to High Education Organization at Palestinian Universities", a research published El Gama El Islamia magazine, Fourteenth volume, Second issue, Palestine, Pp 291.

14.Nour El-Din, B., 2004, "Services Quality and their Effect on Customer SATIFACTIONS", unpublished master thesis, Faculty of Economic Sciences, Management Sciences and Commercial Sciences, Mohamed Bu Dif University, El Masila, Algeria, Pp 146.

15.Omar, F.F., 2005, "Integrated Quality Administration as an Approach for Supporting Strategic Administration at High Education Establishments", a thesis published in strategic administration conference at high education establishments, King Fahd University, Saudi Arabia, Pp 40.

16.Paul, F., 2004, "Quality Management as a systematic management philosophy for use in nonprofit organizations", Unpublished PhD Thesis, Capella University, USA, Pp 89.

17.Prajogo, D. and Brown, A. 2004, "The relationship between TQM practices and quality performance and the role of formal TQM programs: An Australian empirical study", Deakin University, Australia; Unpublished PhD Thesis Edith Cowan University, Perth, Western Australia, Pp 54. 
